\title{
PENGOPERASIAN ALAT TANGKAP TANGKUL UNTUK MENANGKAP BENIH IKAN JELAWAT (Leptobarbus hoeveni Blkr) DI PERAIRAN BATANGHARI JAMBI
}

\author{
Muhtarul Abidin \\ Teknisi Litkayasa pada Balai Riset Perikanan Perairan Umum, Mariana-Palembang \\ Teregistrasi I tanggal: 26 April 2007; Diterima setelah perbaikan tanggal: 10 Mei 2007; \\ Disetujui terbit tanggal: 2 Juni 2007
}

\section{PENDAHULUAN}

Di alam, ikan jelawat (Leptobarbus hoeveni Blkr) (Gambar 1) memijah di bagian hulu sungai selama musim penghujan. Pemijahan ikan ini terjadi di pertemuan sungai utama dan anak sungai. Telur ikan terbawa arus air dan menetas di bagian hilar (Sunarno, 2001).

Bagian hulu sungai (sekitar perairan Bungo Tebo) di musim penghujan merupakan tempat di mana ikan jelawat memijah dan telurnya menetas di bagian hilir sungai (sekitar Sungai Kenali Asam, Danau Teluk, dan Danau Sipin) (Nurdawati, 1993). Pada musim penghujan pada saat telur ikan telah menetas, masyarakat di sekitar daerah aliran Sungai Batanghari Jambi melakukan kegiatan penangkapan benih (fry) ikan jelawat atau kelemak.

Tangkul (lift net) merupakan salah satu alat tangkap benih ikan yang digunakan masyarakat setempat untuk menangkap benih ikan jelawat . Benih ikan selain benih ikan jelawat yang tertangkap tangkul antara lain adalah ikan seluang (Rasbora spp.), juar (Lusiosoma sp.), kapiat (Puntius schwanefeldi), seberuk (Crossochilus cobitis), aromerah mato (Osteochilus melanopleura), si hitam (Labeo chrysopekadion), puyau (Osteochilus hasselti), bentulu (Barbichtys laevis), dan kebarau (Hampala macrolepidota).

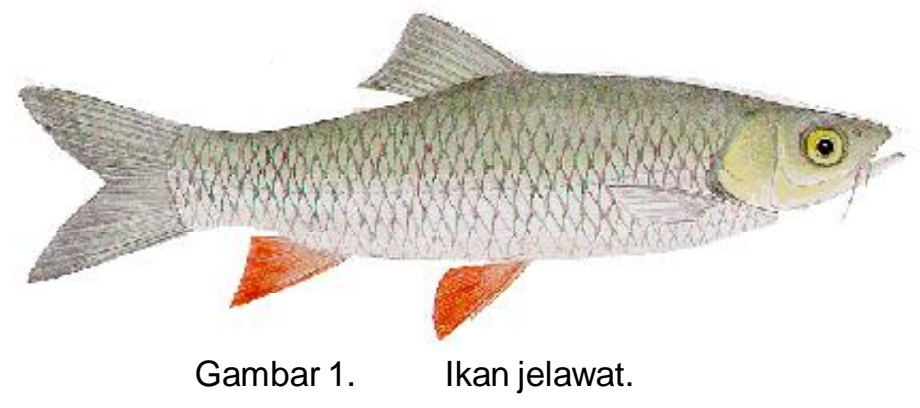

Tujuan penulisan ini adalah untuk menjelaskan teknik pengoperasian alat tangkap tangkul untuk menangkap benih ikan jelawat di daerah aliran Sungai Batanghari, Jambi.

\section{DESKRIPSI ALAT TANGKAP TANGKUL (LIFT NET)}

Bahan waring dengan mesh size $1 \mathrm{~mm}$, ukuran $2,5 \times 2,5 \mathrm{~m}$, tangkai atau gagang dari bambu diameter $3 \mathrm{~cm}$ panjang 2-3 m, kerangka (frame) cabang dari bambu diameter $1,5 \mathrm{~cm}$ berjumlah 4 buah dengan panjang bentangan antara satu dengan yang lain 50$75 \mathrm{~cm}$, penyambung kerangka cabang dengan tangkai 2 buah terbuat dari bambu diameter $1,55 \mathrm{~cm}$ panjang $15 \mathrm{~cm}$ diikatkan dengan tali pada ujung tangkai bambu, sehingga tangkai atau gagang bambu dapat berputar ke segala arah ketika tangkul diangkat (Gambar 2).

\section{MUSIM PENANGKAPAN BENIH IKAN JELAWAT}

Ikan jelawat (Leptobarbus hoeveni Blkr) memijah di alam di bagian hulu sungai (sekitar perairan Bungo Tebo) Batanghari Jambi selama musim penghujan. Pada awal musim penghujan, ukuran benih yang tertangkap berkisar 0,5-1,0 cm (post larva). Pada pertengahan musim penghujan pada benih tertangkap berukuran sekitar 3-5 cm, dan saat akhir musim penghujan tertangkap berukuran $10-15 \mathrm{~cm}$ (jelejar).

\section{Cara Pengoperasian Alat Tangkap (Traps)}

Penangkapan benih (fry) dengan tangkul dilakukan di pinggir-pinggir sungai, danau, dan sawah yang digenangi air. Lokasi yang banyak benih (fry) adalah genangan-genangan air yang terletak tidak jauh dari Sungai Batanghari seperti sungai di sekitar Danau Teluk, Sungai Kenali Asam, dan Danau Sipin. 
Alat tangkap tangkul dioperasikan di tempat terbuka untuk memudahkan pemasangannya (Gambar 3) dan juga dapat di pinggir-pinggir sungai, dilakukan oleh 2 orang. 1 orang mengangkat tangkul, dan 1 lainnya bertugas menyerok atau mengumpulkan benih yang masuk ke dalam tangkul. Benih yang tertangkap berukuran $3-5 \mathrm{~cm}$ (saat pertengahan musim hujan) dan ukuran jelejar $10-15 \mathrm{~cm}$ (pada saat akhir musim hujan).

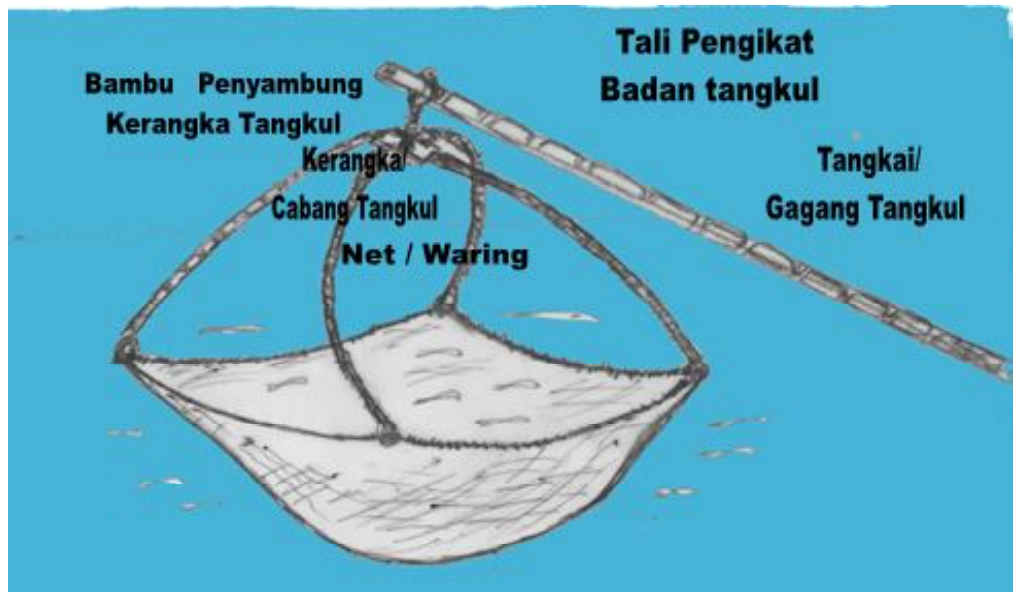

Gambar 2. Alat tangkap tangkul (lift net).

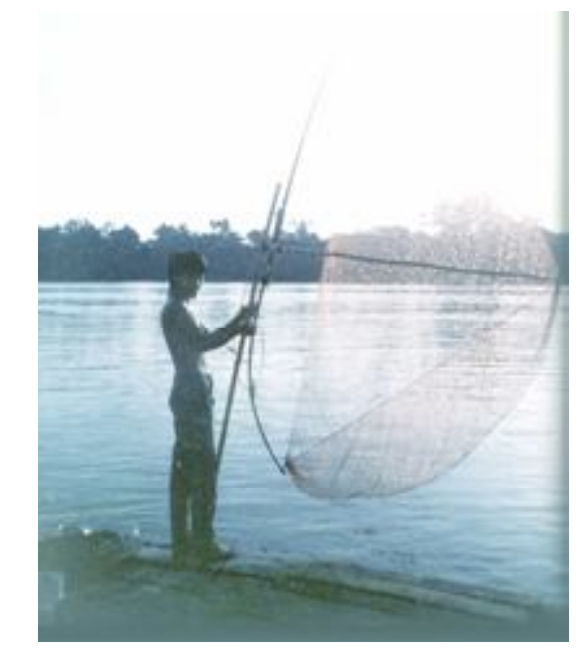

Gambar 3. Cara pengoperasian tangkul.

\section{HASIL TANGKAPAN}

Hasil tangkapan saat musim penangkapan dapat mencapai 10.000-100.000 ekor per hari per nelayan benih berumur 1-3 minggu $(0,5-1,0 \mathrm{~cm})$, sedangkan untuk benih ukuran jari 3-5 cm tertangkap 50-100 ekor per hari per nelayan dan ukuran benih $10-15 \mathrm{~cm}$ tertangkap sekitar 15-20 ekor per hari per nelayan.

Aktivitas penangkapan benih ikan jelawat terjadi 7-10 hari setelah banjir di awal musim hujan dan lama penangkapan berkisar $3-10$ hari (ukuran benih 0,5$1,0 \mathrm{~cm}$ ). Musim penangkapan benih ukuran jari (3-5 $\mathrm{cm}$ ) terjadi pada bulan ketiga di musim hujan, berkisar 7-21 hari. Untuk benih ukuran jelejar $10-15 \mathrm{~cm}$ dimulai akhir musim hujan dan dapat terjadi hampir selama musim kemarau (Tabel 1).

\section{JENIS-JENIS BENIH IKAN LAIN YANG TERTANGKAP DENGAN TANGKUL}

Hasil tangkapan keseluruhan benih yang tertangkap tangkul tidak hanya benih ikan jelawat, namun ada jenis-jenis ikan lainnya (Tabel 2).

\section{KISARAN PANJANG}

Kisaran ukuran ikan hasil tangkapan benih ikan jelawat awal musim penghujan adalah 0,5-1 cm. Benih berumur 1-3 minggu dan ukuran berbentuk larva. Pada saat pertengahan musim hujan, ikan yang tertangkap berukuran jari (3-5 cm), sedangkan pada akhir musim penghujan berkisar $10-15 \mathrm{~cm}$. 
Tabel 1. Ukuran benih (fry) ikan jelawat (L. hoeveni Blkr) yang tertangkap dengan tangkul

\begin{tabular}{cccl}
\hline No. & Ukuran benih (cm) & Jumlah tangkapan (ekor) & \multicolumn{1}{c}{ Musim tangkapan } \\
\hline 1. & $0,5-1,0$ (post larva) & $10.000-100.000$ & Awal musim hujan \\
2. & $3,0-5,0$ & $50-100$ & Pertengahan musim hujan \\
3. & $10,0-15,0$ & $15-20$ & Akhir musim hujan-masuk awal musim hujan \\
\hline
\end{tabular}

Tabel2. Hasil tangkapan benih ikan lain selain benih ikan jelawat ( $L$. hoeveni Blkr) dengan menggunakan tangkul

\begin{tabular}{clcl}
\hline No. & \multicolumn{1}{c}{ Jenis ikan } & No. & \multicolumn{1}{c}{ Jenis ikan } \\
\hline 1. & Seluang (Rasbora spp.) & 6. & Si hitam (Labeo Chrysopekadion) \\
2. & Juar (Lusiosoma sp.) & 7. & Puyau (Osteochilus hasselti) \\
3. Kapiat (Puntius Schwanefeldi) & 8. Bentulu (Barbichtys Laevis) \\
4. Seburuk (Crossochilus Cobitis) & 9. Kebarau (Hampala Macrolepidota) \\
5. & Aromerah mato (Osteochilus melanopleura) & & \\
\hline
\end{tabular}

\section{KARAKTERISTIK BENIH (FRク IKAN JELAWAT}

Benih ikan jelawat mempunyai karakteristik, yaitu terdapat tanda bintik jernih, mata agak menonjol, dan isi perut berwarna hitam berbentuk semacam titik. Serta berenang dengan gerakkan maju-mundur seperti gerakkan ikan terkejut. Tanda-tanda tersebut berlaku untuk benih yang berumur 1-2 minggu. Bentuk tubuhnya lebih lebar bila dibanding dengan ikan seluang (Rasbora spp.), kepala lebih pendek, warna tubuh agak kehitam-hitaman dan isi perut hitam memanjang menyerupai sebuah garis (dapat dilihat pada benih yang berumur 3 minggu lebih). Benih berumur 1 bulan mulai kelihatan sisik yang tumbuh lebih rapat bila dibandingkan ikan lain.

\section{KESIMPULAN}

1 Tangkul merupakan salah satu alat tangkap yang digunakan untuk menangkap benih ikan jelawat (Leptobarbus hoeveni Blkr) pada musim penangkapan di bagian hilir di sekitar Sungai Kenali Asam, Danau Teluk, dan Danau Sipin.
2 Lokasi penangkapan benih dengan tangkul lebih efektif bila dilakukan di tempat terbuka supaya tidak tersangkut ranting-ranting kayu dan memudahkan pengoperasian alat tangkap tangkul.

3 Mesh size dasar kain atau waring untuk tangkul menentukan ukuran benih yang tertangkap.

\section{DAFTAR PUSTAKA}

Nurdawati, S. 1993. Eksploitasi benih (fry) ikan jelawat (Leptobarbus hoeveni Blkr) di perairan umum Jambi. Warta Penelitian dan Pengembangan Pertanian. Departemen Pertanian Republik Indonesia. XV (5): 8.

Sunarno, M., T., D. 2001. Kebutuhan nutrisi benih ikan jelawat (Leptobarbus hoeveni Blkr). Warta Penelitian Perikanan Indonesia. Pusat Riset Perikanan Budi Daya. 7 (3): 6. 